\title{
Integrity and Circumspection: The Labor Law Vision of Bernard D. Meltzer
}

\author{
Theodore J. St. Antoine $\dagger$
}

Bernard Meltzer has testified under oath that he "rarely take[s] absolute positions." The record bears him out. While his colleagues among labor law scholars often strain to demonstrate that the labor relations statutes and even the Constitution support their hearts' desires, ${ }^{2}$ the typical Meltzer stance is one of cool detachment, pragmatic assessment, and cautious, balanced judgment. The "itch to do good," Meltzer has remarked wryly, "is a doubtful basis for jurisdiction" " - or, he would likely add, for any other legal conclusion.

In this brief commentary I propose to examine the Meltzer approach to four broad areas of labor law: (1) the regulation of employer and union economic weapons; (2) labor relations and the antitrust laws; (3) competing and overlapping rights and remedies; and (4) the treatment of racial discrimination. From this overview

$\dagger$ James E. \& Sarah A. Degan Professor of Law, University of Michigan.

1 Wood v. International Bhd. of Teamsters, Local 406, No. G80-742-CA1 (W.D. Mich.), Tr. 4-111 (Oct. 2, 1984) (Meltzer testimony as expert witness).

${ }^{2}$ See, e.g., Blumrosen, Strangers No More: All Workers Are Entitled to "Just Cause" Protection Under Title VII, 2 InDus. ReL. L.J. 519, 520, 563-64 (1978) (Civil Rights Act of 1964 protects employees against unjust dismissal as well as against discrimination because of race, sex, religion, or national origin); Feller, A General Theory of the Collective Bargaining Agreement, 61 CALIP. L. REv. 663, 773 (1973) (collective bargaining agreement is not a contract between employer and employee; neither may bring suit against the other for breach of contract); Gorman \& Finkin, The Individual and the Requirement of "Concert" Under the National Labor Relations Act, 130 U. PA. L. REv. 286, 336-39 (1981) (NLRA protects individual employee protests as well as group employee protests); Klare, Judicial Deradicalization of the Wagner Act and the Origins of Modern Legal Consciousness, 19371941, 62 MinN. L. REv. 265, 284-85 (1978) (original NLRA was designed to give workers an autonomous role in industrial decisionmaking); Peck, Unjust Discharges From Employment: A Necessary Change in the Law, 40 OHIo ST. L.J. 1, 4, 20-42 (1979) (constitutional guarantees of due process and equal protection preclude continuing adherence to at-will employment doctrine). I claim no immunity from the indictment in the text. See St. Antoine, Legal Barriers to Worker Participation in Management Decision Making, 58 TuL. L. REv. 1301, 1305-07 (1984) (substantially all lawful contract proposals should be mandatory subjects of bargaining under the NLRA).

${ }^{3}$ Meltzer, Labor Arbitration and Overlapping and Conflicting Remedies for Employment Discrimination, 39 U. CHI. L. REv. 30, 34 (1971). 
I would say that Meltzer is at his best in the clear-eyed untangling of legislative intent and the even-handed appraisal of opposing interests. He fares less well, I think, in responding to flesh-and-blood exigencies, including the needs and demands of rank-and-file workers.

\section{The Regulation of Economic Power}

Meltzer has recognized that ours is "a labor policy which has evolved no general alternative to the use of economic pressure as a means of breaking a bargaining impasse," and which continues to acknowledge the role of economic weapons in securing representation. ${ }^{5}$ Our labor policy thus requires that lines be drawn between legitimate and illegitimate exercises of economic power. The $\mathrm{Na}$ tional Labor Relations Board and the courts have, in Meltzer's view, too often lapsed into "empty sloganeering," developing "unreal and unworkable distinctions" in this area which evade judicial responsibility and unwittingly encourage unions and employers to resort to crafty rhetoric and disingenuous bargaining tactics. ${ }^{7}$ His approach is well demonstrated by his treatment of lockouts and organizational picketing.

\section{A. The Lockout Cases}

A lockout occurs when an employer voluntarily withholds work from its employees. When Meltzer entered the debate in $1956,{ }^{8}$ the Board had identified three types of lockouts. " $O f f e n-$ sive" bargaining lockouts, designed to apply economic pressure as a means of breaking a deadlock in negotiations, were deemed to be reprisals against concerted activity protected under section 7 of the National Labor Relations Act (NLRA), ${ }^{10}$ and were thus illegal even in the absence of anti-union animus. ${ }^{11}$ Two kinds of defensive lock-

- Meltzer, Single-Employer and Multi-Employer Lockouts Under the Taft-Hartley Act, 24 U. CHI. L. REv. 70, 97 (1956).

${ }^{3}$ Meltzer, Organizational Picketing and the NLRB: Five on a Seesaw, $30 \mathrm{U}$. CHI. L. Rev. 78, 79 (1962) (Taft-Hartley Act reached "only the cruder pressures through which unwanted unions might foist themselves on employees").

- Meltzer, supra note 4, at 80.

Id. at 76-77.

Id. at 80.

- See Meltzer, Lockouts under the LMRA: New Shadows on an Old Terrain, $28 \mathrm{U}$. CHr. L. REv. 614, 614-15 (1961) (discussing Board's categories).

${ }^{10} \mathrm{Ch} .372, \S 7,49$ Stat. 452 (1935) (codified as amended at 29 U.S.C. $\S 157$ (1982)).

1 See, e.g., Morand Bros. Beverage Co., 99 N.L.R.B. 1448, 1460-65 (1952), enforced, 204 F.2d 529 (7th Cir.), cert. denied, 346 U.S. 909 (1953). 
outs were recognized. "Economic" lockouts, which merely seek to keep employers from incurring extraordinary losses due to the timing of an imminent strike, were permitted. For example, an auto dealer's service department, faced with an imminent strike, was permitted to engage in a lockout in order to prevent customers' cars from being tied up in the course of repairs. ${ }^{12}$ Finally, a defensive lockout by members of a multiemployer bargaining unit, in the form of a temporary shutdown, was held to be a lawful response to a union "whipsaw" strike that threatened the unit with disintegration. ${ }^{13}$

In a series of articles, Meltzer argued vigorously that the illegality of offensive bargaining lockouts could not be sustained in the face of the legality of economic and defensive multiemployer lockouts. ${ }^{14} \mathrm{He}$ pointed out quite correctly that the Board's major premise, that any interference with strikes or other protected activity is unlawful, was "manifestly incompatible"15 with employers' long-standing right to replace economic strikers ${ }^{16}$-an option which, when feasible, would be even more deleterious to employee rights and to industrial peace than a bargaining lockout. Meltzer concluded that the Board's line between bargaining and nonbargaining lockouts was untenable: both are economic weapons that may inflict losses on employees as a consequence of concerted action, and both thus inhibit activity protected by the NLRA. ${ }^{17}$ Moreover, he insisted that bargaining lockouts were standard practice before the enactment of the Wagner Act, ${ }^{18}$ and that the Act's explicit recognition of the right to strike was not intended to expand the scope of protected activities by eliminating "the common law legality of lockouts." 19 Most forcibly of all, Meltzer maintained that the Supreme Court itself had acknowledged the exercise of economic power as central to the bargaining process, and had rejected the Board's efforts to equalize disparities in bargaining power. ${ }^{20} \mathrm{He}$ observed that "the apparently unauthorized quest for

12 Betts Cadillac Olds, Inc., 96 N.L.R.B. 268, 289 (1951).

${ }_{13}$ See Buffalo Linen Supply Co., 109 N.L.R.B. 447, 448 (1954), rev'd sub nom. Truck Drivers Local Union No. 449 v. NLRB, 231 F.2d 110 (2d Cir. 1956), rev'd, 353 U.S. 87 (1957).

14 See Meltzer, supra note 4; Meltzer, supra note 9; Meltzer, Lockouts: Licit and Illicit, 16 N.Y.U. CoNF. ON LAB. 19 (1963).

${ }^{15}$ Meltzer, supra note 9 , at 616.

${ }^{16}$ See NLRB v. Mackay Radio \& Tel. Co., 304 U.S. 333, 345-46 (1938).

17 Meltzer, supra note 9, at 628.

18 Ch. 372, 49 Stat. 449-57 (1935) (codified as amended at 29 U.S.C. $\$ \S 151-167$ (1982)).

18 . Meltzer, supra note 4 , at 80.

${ }^{20}$ Meltzer, supra note 9, at 619-20. 
such equalization ... underlies the Board's lockout prohibition" and rejected it accordingly. ${ }^{21}$

Meltzer invested substantial intellectual capital in his thesis that the NLRA permits offensive bargaining lockouts. Yet when the Supreme Court eventually adopted the essence of his position in a celebrated pair of 1965 decisions, Meltzer devoted scant attention to his triumph. Instead, he delivered a penetrating critique of the Court's methodology and the broader implications of its rationale.

The first of these cases, $N L R B$ v. Brown, ${ }^{22}$ involved a union whipsaw strike against one retail food store in a multiemployer bargaining unit. The struck employer continued operations, using temporary help. ${ }^{23}$ In turn the unstruck members of the multiemployer group locked out their union workers, and also remained open by hiring temporary replacements. Prior case law had sustained the right of unstruck members of a multiemployer group to shut down to retain parity when the struck member of the group shut down." As a result of what it saw to be a "critical difference"2s between shutting down and continuing operations with temporary replacements, the Board found that the unstruck employers in Brown had violated sections 8(a)(1) and 8(a)(3) of the NLRA. ${ }^{26}$

In the second case, American Ship Building Co. v. $N L R B,{ }^{27}$ a single employer, the operator of four shipyards on the Great Lakes, reached a bargaining impasse with the unions representing its employees. Fearful that the unions would time a strike to immobilize vessels in the course of repairs or to put pressure on the employer during the busy winter repair period, the employer proceeded to lay off workers in what amounted to a graduated lockout. The shipyards made no effort to hire either temporary or permanent replacements. Rejecting the employer's contention that it had rea-

21 Id. at 620 .

${ }^{22} 380$ U.S. 278 (1965), aff'g 319 F.2d 7 (10th Cir. 1963), denying enforcement to John Brown, 137 N.L.R.B. 73 (1962).

23 This course of conduct was lawful; under NLRB v. Mackay Radio \& Tel. Co., 304 U.S. 333 (1938), the struck employer would even have had the right to hire permanent replacements. See Brown, 380 U.S. at 290.

${ }^{24}$ See NLRB v. Truck Drivers Local Union No. 449 (Buffalo Linen), 353 U.S. 87 (1957).

${ }^{28}$ Brown, 137 N.L.R.B. at 75.

2629 U.S.C. $\S \S 158(a)(1), 158(a)(3)$ (1982).

${ }^{27} 380$ U.S. 300 (1965), aff'g 331 F.2d 839 (D.C. Cir. 1964), enforcing American Ship Bldg. Co., 142 N.L.R.B. 1362 (1962). 
son to fear an imminent strike, ${ }^{28}$ the Board found violations of sections $8(a)(1)$ and $8(a)(3)$ of the NLRA despite failing to consider, as it also failed to consider in Brown, whether there was subjective anti-union animus on the employer's part.

Both Brown and American Ship Building might easily have been decided, as two concurring Justices urged, ${ }^{29}$ on the well-established theory of legitimate "defensive" lockouts: Brown as a multiemployer lockout seeking to preserve the integrity of the group, and American Ship Building as an economic lockout to defend against an ill-timed and particularly harmful strike. But a sixmember majority plainly wished to write a more novel text. ${ }^{30}$ The majority was prepared generally to uphold an employer's use of a bargaining lockout in the absence of discriminatory motivation. For most purposes, the Board later stated, the majority in Brown and American Ship Building had "obliterated" the legal distinction between offensive and defensive lockouts. ${ }^{31}$

Meltzer naturally had no quarrel with that result, and indeed adduced strong historical evidence to support it. ${ }^{32}$ But his principal focus was the Court's failure to "harmonize" the "conflicting themes of its earlier opinions" or to "acknowledge" the difficulty and "make as clean a choice as possible between its own disparate approaches." 33 By this failure, the Court "perpetuated past confusions by implying that they did not exist." 34 The result was a travesty of principled decisionmaking and, perhaps even more important as a practical matter, a substantial default on the Court's major obligation of developing comprehensible, predictive standards for the guidance of lower courts and administrative tribunals.

Earlier, in NLRB v. Insurance Agents International Union, ${ }^{35}$ the Supreme Court had laid down the bedrock proposition that the

28142 N.L.R.B. at 1363, 1364.

28 Justice Goldberg and Chief Justice Warren concurred in Brown, 380 U.S. at 292, and in American Ship Building, 380 U.S. at 327.

${ }^{30}$ Somewhat surprisingly, the Court chose two separate amanuenses, Justice Stewart in American Ship Building and Justice Brennan in Brown, a procedure which may have contributed to the "tension" that Meltzer perceived between the approaches followed in the two opinions. See Meltzer, The Lockout Cases, 1965 SuP. CT. REv. 87, 105.

${ }^{31}$ Evening News Ass'n, 166 N.L.R.B. 219, 221 (1967). This may have been an overstatement. The distinction might still have been significant for issues the Court in American Ship Building had left open: whether a single employer could lock out prior to a bargaining impasse or hire replacements during a lockout. See Brown, 380 U.S. at 308 \& n.8.

32 See Meltzer, supra note 30, at 99-100.

${ }^{33} I d$. at 96.

${ }^{34} I d$.

ss 361 U.S. 477 (1960). 
NLRA did not install the Board as an "arbiter of the sort of economic weapons the parties can use in seeking to gain acceptance of their bargaining demands." ${ }^{\text {36 }} \mathrm{A}$ union may thus resort to nontraditional forms of economic pressure designed to harass the employer, ${ }^{37}$ and an employer may permanently replace economic strikers in order to carry on its business. ${ }^{38}$ Yet in NLRB $v$. Erie Resistor Corp. ${ }^{39}$ the Court had also declared that Congress had committed "primarily" to the Board "the balancing of conflicting legitimate interests . . . to effectuate national labor policy," subject to "limited" judicial review. ${ }^{40}$ The Court held in Erie Resistor that the Board could find it violative of both sections 8(a)(1) and 8(a)(3) of the Act for an employer to grant superseniority to strike replacements, even though the employer was free of anti-union animus and acted solely for legitimate business ends. ${ }^{41}$ Since to the Board's "experienced eye" the "claimed business purpose would not outweigh the necessary harm to employee rights," the Board could "put aside evidence of [employer] motive":42 the "inherently destructive" nature of the conduct "carried its own indicia of intent." 43

Understating the situation, Meltzer commented that "Erie Resistor appeared to sanction the Board's exercise of the power denied to it by Insurance Agents."44 Brown and American Ship Building offered the Court the opportunity to set matters straight. Instead, it straddled the fence. Citing Erie Resistor, the Court reiterated that the Board "need not inquire into employer motivation" if the conduct is "demonstrably destructive of employee rights and is not justified by the service of significant or important business ends." 45 But, echoing Insurance Agents, the Court proclaimed that "[s]ections 8(a)(1) and (3) do not give the Board a general author-

${ }^{36}$ Id. at 497 . This principle apparently still commanded the Court's support at the time of the lockout cases: it was quoted approvingly in Brown, 380 U.S. at 283, and in American Ship Building, 380 U.S. at 317-18.

${ }^{37} 361$ U.S. at 480-81, 495-96 (discussing union's on-the-job actions).

3s NLRB v. Mackay Radio \& Tel. Co., 304 U.S. 333, 345-46 (1938).

373 U.S. 221 (1963).

10 Id. at 236 (quoting NLRB v. Truck Drivers Local Union No. 449 (Buffalo Linen), 353 U.S. 87, 96 (1957).

1373 U.S. at 237.

42 Id. at $230,236-37$.

43 Id. at $228,231$.

14 Meltzer, supra note 30 , at 95.

4 Brown, 380 U.S. at 282-83; cf. American Ship Building, 380 U.S. at 309, 311-12 (unlike the superseniority in Erie Resistor, the lockout is not "one of those acts which are demonstrably so destructive ... that the Board need not inquire into employer motivation"). 
ity to assess the relative economic power of the adversaries in the bargaining process and to deny weapons to one party or the other because of its assessment of that party's bargaining power."46

What does it mean, concretely, to say that the Board may determine that certain conduct is so "destructive" of employee rights as to "carry its own indicia of [unlawful] intent," but that the Board may not "deny weapons to one party or the other because of its assessment of that party's bargaining power"? Why, more specifically, does superseniority fall within the unlawful "inherently destructive" category and permanent replacements and lockouts within the lawful "bargaining weapon" category? What particular evidence should union, employer, or Board counsel assemble to demonstrate that "employee rights" are threatened with "destruction" or, conversely, that challenged conduct is a mere exercise of "bargaining power"? 47

Meltzer recognized that questions involving bargaining lockouts do not turn on "expertise" or the "detailed application of a general standard"- his characterization of the reigning standards as "loose" is overly generous. His comments on the proper role of the courts in this area are highly suggestive, if diplomatically phrased. He stated that there are "strong reasons against limited judicial review of the Board's evaluation of the bargaining lockout."48 At stake are the "basic premises of the statute," the "evenhandedness, the real and apparent integrity, of the regulatory system as it is applied to unions and employers, respectively."49 Such questions "warrant broad judicial review," not the Court's "ritual of deference." Meltzer is too much the gentleman to have come straight out with it, but he seemed to be saying that by 1965 the Kennedy-Johnson Board had become too identified with the interests of organized labor to be trusted with an "impressionistic assessment" of the impact of economic pressures on "that will-o'-

4 American Ship Building, 380 U.S. at 317; see also Brown, 380 U.S. at 283 (the Board is not an "arbiter of the sort of economic weapons the parties can use in seeking to gain acceptance of their bargaining demands") (quoting Insurance Agents, 361 U.S. at 497).

${ }^{47}$ In American Ship Building the Court remarked that "there is no indication, either as a general matter or in this specific case, that the lockout will necessarily destroy the unions' capacity for effective and responsible representation." 380 U.S. at 309. Yet the AFLCIO in American Ship Building had placed before the Court data on the liquid asset holdings of workers at various income levels in order to illustrate their vulnerability to a lockout. Brief for the AFL-CIO as Amicus Curiae at 10-11 \& n.6, American Ship Bldg. Co. v. NLRB, 380 U.S. 300 (1965).

\& Meltzer, supra note 30, at 103.

${ }^{49}$ Id. (emphasis added).

${ }^{s o} I d$. 
the-wisp, 'bargaining power." "s1 $\mathrm{He}$ did not, however, provide much in the way of alternative standards for the courts of appeals that now must flounder about in the areas where the Supreme Court declines to grant certiorari.

A true Meltzerian conclusion capped this appraisal of Brown and American Ship Building. He eschewed any summary of his statutory analysis in favor of a more personal note. Lamenting the Court's unwillingness to face up to the "formidable difficulties" in the lockout cases, he reflected poignantly on the wider manifestations of this disingenuousness: "A fuller acknowledgment of the difficulties would have been welcome as an end in itself at a time when it is only too fashionable to obscure the sources of problems." 52

\section{B. The Problem of Organizational Picketing}

Suppose that Restaurant Workers Local 100 has organized five of the six eateries on Main Street. The employees of the Sugar Bowl, the sixth establishment, oppose unionization. They have refused to sign cards authorizing Local 100 to represent them, have crossed Local 100's picket line, have even voted against Local 100 in a secret-ballot election conducted by the Board. Nevertheless, the union maintains a constant patrol on the public sidewalk in front of the restaurant, complete with large placards denouncing the Sugar Bowl as "Unfair" because it does not have a contract with Local 100. This picketing could be characterized either as "organizational," designed to enlist employees into the union, or as "recognitional," designed to induce the employer to accept the union as its employees' exclusive bargaining agent. For our purposes we can treat it as all the same..$^{53}$

We can easily identify several competing interests and conflicting policy considerations. The Sugar Bowl employees are being coerced to join the union despite their manifest and seemingly free choice. The employer is under economic pressure either to recognize a union that lacks majority support or to force its employees into the union against their will. Either course would violate the NLRA. The union and the Main Street restaurant employees it has organized face the danger that their gains will be undermined

si Id.

s2 Id. at 118.

63 Influential commentators have regarded the distinction as artificial. See Cox, The Landrum-Griffin Amendments to the National Labor Relations Act, 44 MinN. L. Rev. 257, 265 (1959); Meltzer, supra note 5, at 79 \& n.10. 
by competition from the Sugar Bowl, which can exploit the advantages of non-union wages and working conditions. The union may also have some constitutional rights to assert. The interests of the public are more diffuse: some consumers will resent and resist the union's appeals, others are potentially eager allies.

In 1959, Congress struck what Meltzer described as a "murky compromise" 54 among these various interests by adding section $8(b)(7)$ to the NLRA. ${ }^{\text {s5 }}$ The new provision required the Board's election processes to be invoked within thirty days of the onset of organizational picketing, and prohibited organizational picketing entirely if no election were possible because of the incumbency of another union or because a valid election had recently been held. The purport of the section was to accentuate voting and deemphasize picketing as the means of resolving representational disputes.

Meltzer's handling of three knotty interpretive problems presented by section $8(\mathrm{~b})(7)$ illustrates the special blend of pragmatism and principle that characterizes his reading of statutes. Under the procedures of the new provision, the Board must hold an "expedited" election whenever a union engaged in what would otherwise be excessive organizational picketing files a timely election petition. The Board had held in an early case that the picketing union must file an election petition within the statutory period even if the employer has committed an unfair labor practice (except a refusal to bargain under section $8(a)(5)) . .^{\text {s6 }}$ But the Board will not conduct an election until it has processed the pending unfair labor practice charge, and indeed will permit the organizational picketing to continue until it has disposed of the "blocking" charge. ${ }^{57}$ To Meltzer this meant that "the express statutory purpose of avoiding protracted recognitional picketing will be sacrificed in order to achieve untainted elections." election postponement justified: "tainted elections should not govern employee or union representation rights." more troublesome" issue of prolonged picketing, he took comfort from the assurance of the Board's Chicago Regional Office that "blocking charges, where frivolous, are disposed of 'expeditiously'

54 Meltzer, supra note 5, at 81.

ss 73 Stat. 544 (1959) (codified at 29 U.S.C. \$ 158(b)(7) (1982)).

${ }^{66}$ International Hod Carriers Union Local 840 (Blinne Constr. Co.), 130 N.L.R.B. 587 (1961), modified and aff'd on rehearing, 135 N.L.R.B. 1153 (1962).

67135 N.L.R.B. at 1166.

s8 Meltzer, supra note 5 , at 87.

s9 Id. 
and that meritorious charges usually result in a quick settlement and a quick election." ${ }^{\circ 0}$ Understandably, he still thought it would be helpful "to have more precise data concerning the effects and merits of blocking charges."

By their terms, the general prohibitions of section 8(b)(7) apply only to organizational and recognitional picketing. Perhaps to meet possible constitutional objections, a proviso was added that insulates picketing for "the purpose" of "truthfully advising the public" of the nonunion status of the employer even beyond the thirty-day statutory limit, as long as the picketing does not induce stoppages of deliveries or other services. But the proviso is ambiguous: picketing rarely has a single purpose. A divided Eisenhower Board first held that the proviso applied only to "purely informational" picketing, "picketing where the sole object is dissemination of information divorced from a present object of recognition." divided Kennedy Board then reversed, reasoning that the publicity proviso had been rendered meaningless by the prior Board's construction. The main body of section $8(b)(7)$ did not cover nonrecognitional picketing at all; the proviso had no meaning if it only excluded cases which were never included in the statute's general prohibition. The proviso must therefore apply to recognitional picketing that also informs the public, but causes no delivery stoppages. $^{63}$

Meltzer, not without reason, considered the arguments based on the text of "this inelegant proviso . . . evenly balanced," but for him "a practical consideration . . . tip[ped] the scales" in favor of the Kennedy Board's position. ${ }^{64}$ If presence of a recognitional purpose is not determinative of legality, the Board need not confront the "substantial difficulties" of pursuing the "elusive purposes" of the picketing. ${ }^{65}$ The decisive factor instead becomes the objective consequences of picketing - the presence or absence of a stoppage of services.

Meltzer's emphasis on objective consequences and, one may assume, his first-hand knowledge of industrial relations, led him to

so Id. at 88 (footnote omitted).

${ }^{61} I d$.

${ }^{2}$ Local Joint Executive Bd. of Hotel \& Restaurant Employees Int'l Union (Crown Cafeteria), 130 N.L.R.B. 570, 573 (1961), rev'd on rehearing, 135 N.L.R.B. 1183 (1962), aff'd sub nom. Smitley v. NLRB, 327 F.2d 351 (9th Cir. 1964).

${ }^{63}$ See 135 N.L.R.B. at 1184 (adopting dissenting opinion in first decision); 130 N.L.R.B. at 575 (Members Jenkins \& Fanning, dissenting).

ot Meltzer, supra note 5, at 90 (footnote omitted).

os Id. 
challenge the Board on yet another important $8(\mathrm{~b})(7)$ issue. Returning to our Main Street scenario, suppose that Restaurant Workers Local 100 has found the Sugar Bowl to be an unscrupulous and deceitful adversary which it no longer desires to organize. Still, Local 100 does not wish to leave the restaurant free to undercut Main Street's union wages and conditions. So the union sets up what its lawyer characterizes as "purely informational area standards" picketing in front of the Sugar Bowl, calling the public's attention to the existing state of affairs but expressly disclaiming any present or future recognitional objective. Loyal Teamsters spot the pickets and refuse to make deliveries to the Sugar Bowl. Does the picketing violate section $8(b)(7)$ if it exceeds the thirty-day limit? Note that an affirmative answer to the question means that the picketing is illegal; the proviso to section $8(\mathrm{~b})(7)$ is inapplicable because the picketing caused a stoppage of deliveries. The Labor Board has answered the question in the negative, holding that picketing which merely seeks to require an employer to conform to prevailing area standards is legal because it lacks the prohibited organizational or recognitional objective. ${ }^{66}$

In Meltzer's view, the Board's position places too high a premium on the "right rhetoric and cag[iness]."67 To Meltzer, primary picketing is typically aimed at recognition, even if its ostensible purpose is informing the public or protesting substandard conditions. Most important, all primary picketing, regardless of its rhetoric, is likely to trigger the same reaction by employers, employees, and sister unions-and will thus produce the "adverse consequences on employee free-choice" and other abuses that section 8(b)(7) seeks to prevent.

As usual, there is much force and good sense in Meltzer's stance. I cannot rid myself of the notion, however, that certain restrictions on "purely informational" picketing raise grave constitutional questions. ${ }^{68}$ But Meltzer feels otherwise, ${ }^{69}$ and so far the Supreme Court sides with him. ${ }^{70}$ Finally, from a blunter realpolitik perspective, I am concerned with the role that the interpretation of regulations like section $8(\mathrm{~b})(7)$ plays in altering the balance of

${ }^{66}$ Houston Bldg. \& Constr. Trades Council (Claude Everett Constr. Co.), 136 N.L.R.B. 321 (1962).

67 Meltzer, supra note 5, at 91-92.

${ }^{68}$ See St. Antoine, Free Speech or Economic Weapon? The Persisting Problem of Picketing, 16 SufFolk U.L. Rev. 883 (1982). My greatest concern is with picketing addressed to individual, uncoerced members of the consuming public.

Meltzer, supra note 5, at 88-89.

to NLRB v. Retail Store Employees Union Local 1001, 447 U.S. 607 (1980). 
power between labor and management. That balance has shifted almost steadily away from organized labor since the mid-1950s. ${ }^{71} \mathrm{I}$ do not mean to suggest that so complex a phenomenon is attributable to any single factor, including law. But in my view, courts, the Board, and the academic community ought to be concerned with the effects of their positions on the great glacial movements that will ultimately shape the future of industrial relations. Perhaps what Meltzer takes to be evidence of irresponsibility on the part of the Court and the Board is instead evidence that they have chosen to exercise what I take to be the full scope of their responsibility.

\section{LABOR AND ANTITRUST}

Although it is heard much less today, the cry that labor organizations should be subjected to the strictures of the antitrust laws resounded through the halls of Congress, the popular press, and parts of academia during the two decades following the Second World War. ${ }^{72}$ In a 1965 article, Meltzer characteristically began by faulting the "obscurity of [the] suggestion"-the failure of its proponents to identify the union activities their proposal would reach beyond those already covered by labor legislation (such as secondary boycotts) or by the Sherman Act (such as union-employer market divisions). ${ }^{73}$

Labor-antitrust can fairly be called the oldest form of federal labor law. Under classical trade union theory, the aim of unionization is to eliminate wage competition by "organizing all or substantially all firms producing for a common market." " Unions are thus inherently monopolistic. Yet by the time federal antitrust law su-

7 In 1954 over 38 percent of private nonagricultural employees were unionized; that figure fell to 30 percent by the mid-1960s and to 24 percent by 1980 . R. Freeman \& J. Medoff, What Do Unions Do? 222, figure 15-1 (1984). It is still falling, and may now be below 20 percent. See BNA Survey on Union Membership Statistics, 117 LAB. REL. REP. (BNA) 81 (Oct. 1, 1984).

${ }^{72}$ See Meltzer, Labor Unions, Collective Bargaining, and the Antitrust Laws, $32 \mathrm{U}$. Cri. L. Rev. 659, 704-14 (1965) (considering proposals); see also Cox, Labor and the Antitrust Laws-A Preliminary Analysis, 104 U. P. L. REv. 252, 252-53 (1955) (critiquing the conclusions of the 1955 Report of the Attorney General's National Committee to Study the Antitrust Laws, which concluded that some union activities ought to be made subject to the antitrust laws); Sovern, Some Ruminations on Labor, the Antitrust Laws and Allen Bradley, 13 LAB. L.J. 957, 957-60 (1962) (discussing proposals and concluding that antitrust laws provide adequate protection).

${ }^{73}$ Meltzer, supra note 72, at 660 .

34 Id. at 660 n.5; see also S. WebB \& B. WeBb, Industrial Democracy $173-79$ (2d ed. 1920) (describing the method of collective bargaining). 
perseded the common law as the principal brake on restrictive commercial practices, the courts had ceased to view the exercise of union monopoly power, as such, as an illegal act. ${ }^{75}$ Under early federal antitrust law, the garden-variety "primary" strike was lawful;"76 but "boycotts," insofar as they suppressed interstate competition and were thus within the scope of federal power, were unlawful. ${ }^{77}$ From that point on, federal labor-antitrust law developed during a period of radical change in public policy toward organized labor. This history guarantees that the case law will defy simple rationalization. Even so, from approximately 1945 to 1965, a plausible summation of the Supreme Court's contemporary teachings on labor-antitrust could have read as follows: The Sherman Act ${ }^{78}$ applies only to a "restraint upon commercial competition in the marketing of goods and services," competition based on differences in labor standards." a matter of a statutory "labor exemption"; the Sherman Act, as written, covers only the product market, not the labor market. ${ }^{81}$ On the other hand, the Clayton ${ }^{82}$ and Norris-LaGuardia ${ }^{83}$ Acts, taken together, introduced a true exemption for a union acting alone in its own interest and not combining with nonlabor groups. ${ }^{84}$ The obvious corollary, announced in the famous Allen Bradley case, was that labor organizations lose their immunity when they "aid nonlabor groups to create business monopolies and to control the marketing of goods and services."8s

Meltzer would probably regard the foregoing encapsulation as overly simplified, especially in its sharpening of the line between

${ }^{75}$ See, e.g., Commonwealth v. Hunt, 45 Mass. (4 Met.) 111, 128-32 (1842).

${ }^{76}$ See UMW v. Coronado Coal Co., 259 U.S. 344 (1922). But cf. Coronado Coal Co. v. UMW, 268 U.S. 295 (1925) (primary strike with actual intent to bar nonunion product from interstate market is Sherman Act violation).

${ }^{77}$ See Bedford Cut Stone Co. v. Journeymen Stone Cutters Ass'n, 274 U.S. 37 (1927); Loewe v. Lawlor, 208 U.S. 274 (1908).

${ }^{78}$ Ch. 647, § 1, 26 Stat. 209 (1890) (codified at 15 U.S.C. $\$ 1$ (1982)).

79 Apex Hosiery Co. v. Leader, 310 U.S. 469, 495 (1940) (footnote omitted).

${ }^{80}$ Id. at 503.

${ }^{81}$ See Connell Constr. Co. v. Plumbers \& Steamfitters Local Union No. 100, 421 U.S. 616, 621-23 (1975). See generally St. Antoine, Connell: Antitrust Law at the Expense of Labor Law, 62 VA. L. REv. 603, 604-08 (1976) (presenting a historical survey of the Court's treatment of Sherman Act claims against unions).

${ }^{82}$ Ch. 323, § 6, 38 Stat. 731 (1914) (codified at 15 U.S.C. $\S 17$ (1982)) ("the labor of a human being is not a commodity or article of commerce"); ch. $323, \S 20,38$ Stat. 738 (1914) (codified at 29 U.S.C. $\$ 52$ (1982)) (restricting labor injunction).

${ }^{83}$ Ch. 90, 11,47 Stat. 70 (1932) (codified at 29 U.S.C $\S 101$ (1982)).

84 See United States v. Hutcheson, 312 U.S. 219, 232 (1941).

${ }^{85}$ Allen Bradley Co. v. Local Union No. 3, Int'l Bhd. of Elec. Workers, 325 U.S. 797, 808 (1945). 
the labor and product markets, ${ }^{86}$ but I think it serves as a useful background to Meltzer's own comments and recommendations. Meltzer showed some sympathy for antitrust legislation that would prohibit union participation in price fixing, market divisions or exclusions, and direct limitations on production or sales-classic "product market" restrictions-notwithstanding the "difficult questions arising from the shadowy lines between labor markets and final product markets." ${ }^{\prime \prime} \mathrm{He}$ distinguished those kinds of product-market restraints from restrictions on hours of work or other incidents of the employment relationship. Price fixing and other direct product-market constraints should, he argued, be prohibited regardless of whether they were accomplished through parallel agreements with individual employers or through the type of agreements with employer "groups" condemned in Allen Bradley. ${ }^{88}$ Restraints stemming from agreements regarding employment conditions should be immunized from the antitrust laws even if originated by employers rather than by unions, and even if the employer could be shown to have the specific purpose of affecting the product market. In both cases, Meltzer's position was based on the rejection of "distinction[s] of no practical significance to the interest at stake."8s Meltzer argued persuasively that his rule recognized that employers may be acting on the basis of a legitimate interest, be it economic or social, in the welfare of their employees. More important, Meltzer rejected any test which would "make legality turn on issues of motivation that are both difficult of proof and largely irrelevant to the issue of whether competition has been restrained," and which as a practical matter are "likely to promote disingenuous rhetoric and mock resistance" by employers. ${ }^{90}$

Meltzer's pragmatic instincts were also at the fore in his reso-

so See Meltzer, supra note 72, at 668.

87 Id. at 705.

sa Id. at 704, 713. The Supreme Court subsequently seems to have agreed on the latter point. See, e.g., Local Union No. 189, Amalgamated Meat Cutters v. Jewel Tea Co., 381 U.S. 676,689 (1965) ("that the parties to the agreement are but a single employer and the unions representing its employees does not compel immunity") (White, J., announcing the judgment of the Court).

s9 Meltzer, supra note 72 , at 672.

9o Id. at 705. Curiously, Meltzer did not mention that his position was consistent with that of Justice Stone in Apex Hosiery Co. v. Leader, 310 U.S. 469 (1940). Stone apparently accepted the notion that antitrust liability simply does not extend to certain restraints, regardless of whether they are brought about by unions or by employers. See id. at 512 (calling for "impartial application of the Sherman Act to the activities of industry \& labor alike"); cf. Kennedy v. Long Island R.R., 319 F.2d 366, 372-73 (2d Cir.) (holding mutual aid agreement among employers in case of strike immune from antitrust laws), cert. denied, 375 U.S. 830 (1963). 
lution of other troublesome questions. As to the appropriateness of antitrust liability for the anticompetitive effects of union opposition to technological change, he felt that any effort to distinguish between "'good faith demands' for cushions against change and ostensible demands for such cushions that are in fact directed at blocking change altogether" should be resisted because of its likely adverse impact on the bargaining process. ${ }^{91}$ Meltzer also rejected the more radical proposals of the day to reduce the monopoly power of unions by eliminating national unions or industry-wide bargaining. His reasoning is a classic illustration of his general approach to emotionally charged issues. Meltzer saw that these proposals were so controversial as to be politically impractical. Nonetheless he was sympathetic to them in principle: they at least had "the virtue of emphasizing that if regulation is to curb union power, it must confront and deal with its sources rather than with its symptoms." 92 In a passage that exhibited the kind of clearminded analysis he so often found lacking in courts, Meltzer did not shy away from the opposition such proposals would engender, since "similar objections are to be expected against any serious attempts to limit union power." the proposals were flawed on the merits: they would have the greatest impact on industries in which unions were weakest, a "plainly perverse" outcome. ${ }^{94} \mathrm{He}$ concluded on a modest note: his own struggles to refine proposals to limit union power had "not been fruitful,"9s and although specific recommendations or "a general endorsement of the existing structures of power" would be "congenial," "such a happy ending would involve either a disregard of what appear to be serious power imbalances or a conscious disregard of the limits of my own ignorance."96

After the completion of the principal portion of Meltzer's 1965 article, but before its publication, the Supreme Court decided two major antitrust cases. In United Mine Workers v. Pennington, ${ }^{97}$ the union entered into an agreement with a group of large coal companies, aiming to increase wages to a level that smaller nonmechanized operators could not meet. The Court held that "there are limits to what a union or an employer may offer or extract in

\footnotetext{
91 Meltzer, supra note 72 , at 707.

92 Id. at 711-12.

93 Id. at 710 .

94 Id. at 711 .

${ }^{95}$ Id. at 712.

${ }^{96}$ Id. at 714 .

${ }^{97} 381$ U.S. 657 (1965).
} 
the name of wages." A union "forfeits" its antitrust "exemption" when it is "clearly shown that it has agreed with one set of employers to impose a certain wage scale on other bargaining units," even though the union's role is limited to securing uniform wages, hours, or working conditions.99 In Local Union No. 189, Amalgamated Meat Cutters v. Jewel Tea Co., ${ }^{100}$ on the other hand, a butchers' union was held to be within its antitrust exemption when it obtained a multiemployer contract restricting night sales of fresh meat. The restriction on marketing hours, while a direct restraint on the product market, was found to be "intimately related" to the butchers' working conditions; the union was found to have secured the provision in pursuit of its own labor policies through arm's length bargaining, rather than in furtherance of a union-employer conspiracy. ${ }^{101}$

Meltzer added an epilogue to his article in which he observed ruefully that the Court had turned his suggestion "on its head by condemning a bargain about wages on the ground that it was actuated by predatory purposes while upholding a market restriction on the ground that its purpose was limited to protecting the legitimate interests of employees." 102 He proceeded to spell out some of the disturbing implications of the Court's latest handiwork.

According to Meltzer, Pennington's condemnation of labor contracts with extra-unit ramifications ignored two major dimensions of labor-antitrust law: the long-standing acceptance of multiemployer bargaining and the tolerance of "the imposition of uniform rates on competitors whatever the differences in their labor markets-the union aside."10s Meltzer saw signs that "the law, having swallowed an anti-competitive whale, was gagging at what, at best, was a minnow." ${ }^{104} \mathrm{He}$ also raised characteristic concerns with the practical effects of the Court's approach. To protect themselves against allegations of extra-unit or predatory agreements, unions and employers would be tempted to resort to "disingenuous bargaining and unnecessary economic warfare" instead of the frank and open exchanges that are the ideal of collective bargaining. ${ }^{105} \mathrm{He}$ was troubled even more by a potential return to ju-

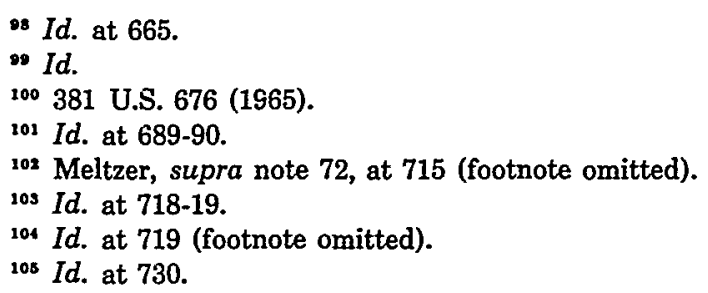


dicial regulation of the substance of collective agreements; the contention in a case like Pennington that wage scales were set "too high" implies that fact-finders are to be invited to substitute their judgment for that of the employer and the union.

Meltzer agreed with Justice Goldberg's argument in dissent in Pennington that there are serious difficulties in "giving decisive effect to motive or purpose as a basis for denying exemptions to collective bargains covering wages" and other working conditions. ${ }^{106}$ This is no surprise, given Meltzer's general aversion to subjective standards. But Meltzer rejected Justice Goldberg's bright-line rule that "labor's exemption from the antitrust laws should be co-extensive with the area of mandatory bargaining." 107 I am not sure why Meltzer, prepared to reject the majority's view, balked at Justice Goldberg's solution. But I believe that his hesitation does not stem from a rejection of the position on the merits. Rather, Meltzer was more likely to have exercised caution because Justice Goldberg's test might in the end be taken to require the labor board to exercise primary jurisdiction over these questions-an outcome which Meltzer heartily and properly rejected. ${ }^{108}$

Jewel Tea presented a confused picture. The Court produced three separate opinions, each signed by three Justices; Justice White expressed the closest thing we have to the position of the Court. At one point, Justice White seemed to be "weighing" the employees' interest in job content and working hours against the admittedly adverse effects of the marketing restrictions on product competition. ${ }^{108}$ When it came to striking the balance among all the factors in this particular case, however, Justice White was guilty of Meltzer's accusation that he "emphasized the union's interests but was wholly silent about the competing interest in competition in the product market."110

More concretely, the restriction on the sale of fresh meat at night was quietly accepted as exempt from the Sherman Act because it was not conspiratorial and was "intimately related" to the employees' dual interest in controlling their jobs and in not working at night. But nothing was said about how minuscule any injury to this interest would be were the grocery chains allowed to oper-

${ }^{108}$ Id. at 731, 729-30 (referring to Justice Goldberg's opinion, 381 U.S. at 697).

107 Id. at 731.

108 See id. at 696-701, 731-34. Meltzer's view prevailed on this issue: the Supreme Court in Jewel Tea rejected the argument that the Board had exclusive primary jurisdiction. See 381 U.S. at $684-88$.

${ }^{109}$ See 381 U.S. at 691.

${ }^{120}$ Meltzer, supra note 72, at 724-25. 
ate self-service meat departments at night. ${ }^{111}$ Nor did Justice White discuss whether the existence of contract provisions dealing directly with job content and working hours would affect the analysis. Finally, no attention was paid to the other side of the scale. The substantial interests of the public-Chicagoans who had to work all day and who wished to shop for meat at night-ought to have been considered. Their stake in this long-running dispute was never mentioned. The larger public policy of preventing restraints on competition for their patronage was given lip-service at best.

Meltzer's treatment of labor-antitrust is of a piece with his overall response to labor questions. He shied away from the pursuit of slippery subjective factors such as purpose or motive, preferring to rely on objective consequences. He paid scrupulous attention to every fact or argument that could be marshalled, including those that cut against his own predilections. And always he decried the "abdication" by Congress of its duty to provide clear standards, and the failure by the members of our highest Court to honor their responsibility "to state clearly and to grapple with the problems raised by the competing approaches of their colleagues and by the precedents." 112

\section{Choice of Law and Choice of Forum}

Meltzer's penchant for the meticulous balancing of opposing interests would seem to mark him as an ideal commentator on questions concerning the proper relationship between federal and state law and between public and private tribunals in the labor field. If we expect our commentators to be accurate predictors of the development of the law, however, this expectation has been only partly realized. Meltzer's approach to arbitration has largely prevailed. But while his analysis of federal preemption is as probing and comprehensive as anticipated, as a prophet he suffers from the defects of his virtues. For Meltzer is like the fabled Fox, which knows many things, while the Warren Court majority that was dominant during the formative years of federal preemption doctrine was more like the Hedgehog, which knows the one big thing. And the one big thing was to ensure the primacy of a uniform national labor policy by excluding state regulation of conduct that

"The trial court had found that it was "impractical" to operate meat departments at night without butchers or other employees. The court of appeals did not reach this finding, and the Supreme Court concluded that the trial judge's "ultimate findings were [not] clearly erroneous." See 381 U.S. at 694, 694-97.

${ }^{112}$ Meltzer, supra note 72 , at 734. 
was even "arguably" protected or prohibited by the NLRA. ${ }^{113}$ That made Meltzer a less than reliable predictor of federal preemption developments during the twenty years following his principal contribution to the field in the late 1950 s. $^{114}$ As we shall see, he has fared better with the advent of a new Burger Court majority.

\section{A. Federal Preemption}

In neither the Wagner Act nor the Taft-Hartley Act did Congress address in general terms the problem of allocating authority over labor relations between the federal and state governments. ${ }^{115}$ Yet Meltzer was surely correct that the Taft-Hartley proponents favored "states' rights." 116 Despite legislative history which Meltzer believed indicates an absence of intent to "obliterate" state power over labor relations, the Supreme Court in the Vinson and Warren eras moved boldly ahead to establish an exclusive system of federal regulation, along with comprehensive preemption of state authority. Meltzer's particular views can best be illuminated by examining some situations in which the tide of decision in that era ran against him, some in which his position prevailed, and some in which more recent developments have finally vindicated his judgment.

Meltzer perceived early that labor law could not live with "primary jurisdiction," the requirement that a state tribunal refrain from adjudicating a labor-related case until the Board has acted and has thereby indicated the scope of state authority. ${ }^{117}$ There simply is not time for a two-step procedure in the ordinary case. As a practical matter, then, the Board's interpretation of the labor laws can be primary only if it is exclusive. Meltzer argued against exclusivity largely on grounds of congressional intent. $\mathrm{He}$ also closely examined the public policy arguments in support of the contrary position, and found them wanting. ${ }^{118}$ To Meltzer, the values of federalism suggested that "uniformity" was not to be an end

${ }^{123}$ San Diego Bldg. Trades Council v. Garmon, 359 U.S. 236, 245 (1959).

${ }_{114}$ Meltzer, The Supreme Court, Congress, and State Jurisdiction over Labor Relations (pts. I \& II), 59 Colum. L. Rev. 6, 269 (1959).

${ }_{115}$ See id. at 8-9. Certain specific federalism issues were covered in the NLRA, among them the Board's power to cede jurisdiction to state agencies, section $10(\mathrm{a})$, ch. $372, \S 10$ (a), 49 Stat. 453 (1935) (codified at 29 U.S. $\S 160(a)$ (1982)), and the power of the states to regulate union security agreements, section $14(\mathrm{~b})$, ch. $372, \S 14(\mathrm{~b}), 49$ Stat. 457 (1935) (codified at 29 U.S.C. \& 164(b) (1982)).

${ }^{116}$ Meltzer, supra note 114, at 20.

117 Id. at 19.

118 Id. at $20-25$. 
in itself; states should be permitted to act as long as their actions were consistent with national standards. He rejected total state preemption as a way to prevent competition in the enactment of "pro-management laws," in part because "a vast body of state law of general application . . . impinges on labor relations" and would thus be swept away by the principle. ${ }^{119}$ Despite his sympathy for efforts to avoid excessive resort to fine lines of distinction between appropriate federal and state spheres, Meltzer, as one "bred in the common law tradition," refused to "ignore the need for discriminating distinctions directed at achieving some rational development of statutory and social purposes."120 There are, in short, political and social values "beyond the quiet life for judges and lawyers."121 Finally, Meltzer rejected the view that the federalist values of local autonomy, diversity, and experimentation would be adequately protected by assigning to the states exclusive control over small businesses; the systematic differences between small and large enterprises would render the states a poor laboratory were their experiments so restricted..$^{122}$

By early 1959, when Meltzer's views on preemption were published, the Supreme Court was already on record against several of his positions. The Court had invalidated a state statute that required pre-strike mediation and an affirmative employee strike vote: since the NLRA protected peaceful picketing for higher wages, that "closed [the field] to state regulation." ${ }^{23}$ Even a state's interest in maintaining essential services was held not to justify a statute prohibiting strikes and lockouts and requiring compulsory arbitration in certain labor disputes involving public utilities. ${ }^{124} \mathrm{As}$ a final blow, the Supreme Court decided the leading preemption case of San Diego Building Trades Council v. Garmon ${ }^{\mathbf{1 2 5}}$ in mid1959 and effectively embraced the broad preemption doctrine op-

119 Id. at 22.

$120 I d$.

121 Id. at 23. Of course, on other occasions Meltzer has given considerable weight to the practical problem of drawing fine distinctions. See, e.g., supra notes 65, 90 and accompanying text.

122 Meltzer, supra note 114, at 23.

123 UAW v. O'Brien, 339 U.S. 454, $457-58$ (1950).

124 Amalgamated Ass'n of Street Employees, Div. 998 v. Wisconsin Employment Relations Bd., 340 U.S. 383 (1951). But cf. United Constr. Workers v. Laburnum Constr. Corp., 347 U.S. 656, 669 (1954) (holding that states may grant tort remedies as result of violence in a labor dispute); UAW v. Russell, 356 U.S. 634, 641-42 (1958) (upholding state law action by employee against union for interference with access to workplace due to mass picketing and threats of violence).

125359 U.S. 236 (1959). 
posed by Meltzer. The Court declared in Garmon that if "an activity is arguably subject to $\S 7$ or $\S 8$ of the Act, the States . . . must defer to the exclusive competence" of the Board. ${ }^{126}$

Later the Court was to reject explicitly another argument Meltzer made at this time. Section 14(b) of the NLRA expressly authorizes state legislatures to forbid union security agreements. Meltzer argued that this grant of authority "should apply not only to consummated hiring arrangements, but also to antecedent pressures [i.e., strikes or picketing] directed toward their achievement.". 27 The Court, in contrast, held that picketing "lies exclusively in the federal domain . . . because state power, recognized by $\S 14(\mathrm{~b})$, begins only with the actual negotiation and execution of the type of agreement described by $\& 14(b) . " 128$ That highly literal reading finds policy support in the inherent ambiguity of most picketing. There was a risk that a state judge in a right-towork jurisdiction, armed with the expected predisposition and a convenient verbal formula, could have enjoined just about any picketing under the proposed broader interpretation of section 14(b). Meltzer was aware of this risk, but thought that the general grant of power to the states under section 14(b) itself resolved similar doubts in favor of state regulation. ${ }^{129}$

In contrast to the reception given Meltzer's views on preemption in other areas, his analyses of federal-state questions have fared well in tracking the main lines of Supreme Court developments regarding the enforcement of collective bargaining agreements. In 1958 the tour-de-force that was Textile Workers v. Lincoln Mills ${ }^{130}$ sustained the constitutionality of section 301 of the Taft-Hartley Act, ${ }^{131}$ which in terms had merely granted jurisdiction to the federal district courts over suits involving union-employer contracts, by decreeing that the provision directed the judiciary to fashion a whole new body of federal substantive law to govern the enforcement of labor agreements. Meltzer did not pause to examine the majority's opinion in Lincoln Mills, the methodology of which (at the very least) must have been somewhat startling to this cautious craftsman. Instead he immediately turned to the

${ }^{128}$ Id. at 245.

127 Meltzer, supra note 114, at 46-47.

${ }^{128}$ Retail Clerks Local 1625 v. Schermerhorn, 375 U.S. 96, 105 (1963) (emphasis in original) (citations omitted); see also Local 438, Constr. \& Gen. Laborers v. Curry, 371 U.S. 542 (1963).

${ }^{129}$ Meltzer, supra note 114 , at 47.

130353 U.S. 448 (1957).

${ }^{131}$ Ch. 120 , title III, $\S 301,61$ Stat. 156 (1947) (codified at 29 U.S.C. $\$ 185$ (1982)). 
several unanswered questions left in its wake. ${ }^{132}$

Meltzer correctly anticipated that the desirability of maintaining uniformity in the application of collective bargaining agreements would lead the Court to make federal substantive law under section 301 exclusive, ${ }^{133}$ but that the obvious purport of the provision to widen the range of available fora would also lead the Court to allow state courts to exercise jurisdiction over suits to enforce labor contracts. ${ }^{134}$ Furthermore, Meltzer anticipated the dilemma that would emerge when the Court faced the issue of remedies: how was uniformity to be achieved in light of the conflict between the ban on federal injunctions against strikes under the Norris-LaGuardia Act and the states' power to provide such equitable relief?

As Meltzer observed, and as the Supreme Court later held, ${ }^{135}$ the Congress that enacted section 301 had "deliberately declined to lift the restrictions of the Norris-LaGuardia Act from the federal courts."136 Yet there was no indication of a purpose similarly to limit state remedies, and states without parallel "little" NorrisLaGuardia restrictions continued to issue injunctions against strikes in breach of contract. ${ }^{137}$ Meltzer apparently leaned towards promoting uniformity by extending the Norris-LaGuardia ban to state courts in contract actions, despite the "ironic twist" that section 301 would then narrow rather than broaden available remedies. ${ }^{138}$ But Meltzer was too much the good lawyer to foresee that the Supreme Court would eventually overrule itself and conclude, in the landmark Boys Markets case, ${ }^{138}$ that Congress had actually authorized at least a partial "accommodation" between the terms of the Norris-LaGuardia Act and the policy of section 301. After that case, Norris-LaGuardia notwithstanding, federal courts could enforce a contractual no-strike clause by enjoining a strike over a grievance that the union was entitled by contract to take to arbitration. ${ }^{140}$

132 See Meltzer, supra note 114, at 276-81.
1s3 See Local 174, Teamsters v. Lucas Flour Co., 369 U.S. 95, 102-04 (1962).
134 See id. at 101 n.9; Charles Dowd Box Co. v. Courtney, 368 U.S. 502 (1962).
135 See Sinclair Refining Co. v. Atkinson, 370 U.S. 195, 203-10 (1962).
136 Meltzer, supra note 114, at 281.
${ }_{137}$ See, e.g., McCarroll v. Los Angeles County Dist. Council of Carpenters, 49 Cal. 2d 45, 63-64, 315 P.2d 322, 332 (1957), cert. denied, 355 U.S. 932 (1958).

13s Meltzer, supra note 114, at 279-81. Union removal of section 301 suits from state to federal courts, see Avco Corp. v. Aero Lodge No. 735, Int'l Ass'n of Machinists, 390 U.S. 557 (1968) (permitting removal under 28 U.S.C. $\$ 1441$ ), would have reduced the federal-state deviations in any event.

139 Boys Markets, Inc. v. Retail Clerks Union, Local 770, 398 U.S. 235 (1970).

1so See id. at 249-53. 
Meltzer is at his insightful best in dealing with the division of responsibility for determining mixed questions of contract and statutory interpretation. Such overlaps are common occurrences. A collective bargaining agreement may forbid anti-union discrimination that is also prohibited by the NLRA. ${ }^{141}$ A striking union may interpose the defense that the contract's general no-strike clause does not, as a matter of law, cover a walkout triggered by the employer's unfair labor practices. ${ }^{142}$ Or, most problematically, a contract suit may raise an issue peculiarly involving Board expertise, such as the representational capacity of the signatory union. ${ }^{143}$ In all three situations, Meltzer would generally allow the court (or an arbitrator) to proceed without prior Board adjudication of the statutory issues. ${ }^{144}$ His views have largely prevailed. ${ }^{145}$

His reasons are both theoretical and practical. The earlier, classic preemption cases involved the enforcement of "obligations imposed by the coercive power of the state," not "obligations voluntarily assumed by the parties." 146 Were preemption the rule in contract enforcement cases, the national policy favoring the use of arbitration could otherwise be undercut by an "artificial fragmentation of the arbitrator's jurisdiction."147 In addition, Meltzer suggested that the rejection of preemption would be good medicine for the courts: an expansive view of judicial power to enforce contracts, while forcing the courts to face "difficult and specialized issues," would "reduce the possibility that undue preoccupation with so-called 'expertise' and with 'uniformity' would result in the denial of prompt and comprehensive relief."148

Almost as an aside, Meltzer identified at this early stage a problem that the Supreme Court laid to rest only years later. Suppose a union engages in "stranger" (nonemployee) picketing on an

${ }^{141}$ See Meltzer, supra note 114, at 282-89.

${ }^{142}$ See id. at 289-92.

143 See id. at 292-95.

144 Meltzer appeared to see the arguments in the representation case as closely balanced, but to have rejected primary jurisdiction in part because courts acting in equity were to be trusted to withhold relief where administrative remedies were adequate or future administrative action is likely to nullify the judicial remedy. See id. at 295 \& n.279.

${ }_{165}$ See, e.g., Carey v. Westinghouse Elec. Corp., 375 U.S. 261 (1964) (arbitration of jurisdictional dispute); Smith v. Evening News Ass'n, 371 U.S. 195 (1962) (suit on contract for damages for antiunion discrimination).

${ }_{148}$ Meltzer, supra note 114, at 286. Oddly, Meltzer did not argue that unlike the preemption cases involving a potential clash between state law and sections seven and eight of the NLRA, the question of judicial authority under section 301 presents the issue of accommodating several presumably coequal provisions of the same federal statute.

147 Id. at 288.

${ }^{148} I d$. at 295 (footnote omitted). 
employer's parking lot, seeking recognition, when it still represents only a minority of the employees. The picketing might arguably be protected by the NLRA as the union's only feasible means of reaching the employees, ${ }^{149}$ and it might arguably be prohibited as a violation of section $8(\mathrm{~b})(7)$ 's limitations on organizational and recognitional picketing. The employer can ordinarily get a ruling on the "arguably prohibited" side of the question by filing a charge under section 8(b)(7). If the General Counsel dismisses the charge, all can safely conclude that the union has not engaged in prohibited conduct. But the possibility that the picketing is protected remains open. Unfortunately for the employer, as Meltzer recognized, that issue cannot be resolved absent some action or threat by the employer against the picketers, followed by the filing of unfair labor practice charges against the employer. ${ }^{150}$

Meltzer posed this dilemma as a basis for his conclusion that state courts should be allowed to enjoin minority recognitional picketing, ${ }^{151}$ a position plainly at odds with subsequent expansive developments in preemption law. ${ }^{152}$ But his views retain their force in the context of state laws of general application, such as antitrespass statutes. Only in 1978 did the Supreme Court finally hold that a state could enjoin peaceful trespassory picketing that was both arguably protected and arguably prohibited by federal labor law. ${ }^{153}$ The Court reasoned that the state's action would not interfere with federal prohibition of unfair labor practices, because such an injunction would not concern the nature of the picketing but rather the separate question of its location. ${ }^{164}$ As to the possibility that protected conduct was in jeopardy, the Court was satisfied that that likelihood was remote, given that trespassory activity by nonemployees is only rarely found to be protected under the NLRA. ${ }^{165}$ The overriding practical consideration, as Meltzer had recognized two decades earlier, was that "the party who could have

${ }^{240}$ See NLRB v. Lake Superior Lumber Corp., 167 F.2d 147, 150-51 (6th Cir. 1948); cf. Republic Aviation Corp. v. NLRB, 324 U.S. 793, 799 (1945) (suggesting a strict standard for infeasibility of alternative access).

1so Meltzer, supra note 114, at 18-19.

151 Id. at 24-25.

${ }^{152}$ See, e.g., Lodge 76, Int'l Ass'n of Machinists v. Wisconsin Employment Relations Comm'n, 427 U.S. 132, 144-48 (1976) (even conduct that is neither protected nor prohibited by the NLRA cannot be regulated by the states if it is central to the federal statutory scheme and is thus intended by Congress to be left to the free play of economic forces).

${ }^{163}$ Sears, Roebuck \& Co. v. San Diego County Dist. Council of Carpenters, 436 U.S. 180 (1978).

${ }^{184}$ Id. at 197-98.

${ }^{15 s}$ Id. at 204-07. 
presented the protection issue to the Board has not done so and the other party to the dispute has no acceptable means of doing so."156 Once again, Meltzer's reasoning had prevailed.

\section{B. The Arbitrator and the Law}

A simpler, more casual, and, perhaps for those reasons, more incisive Meltzer is revealed in a graceful little paper he delivered at the annual meeting of the National Academy of Arbitrators in 1967. ${ }^{187}$ Among his themes were two of the most persistent and divisive issues in labor arbitration: What is the proper standard for judicial review of an arbitral award? What should an arbitrator do when confronted with a direct conflict between the terms of a collective bargaining agreement and the provisions of applicable statutory or common law?

Meltzer made the quite sensible suggestion that "the courts in actions involving the validity of the award should have more responsibility for the merits than in actions to compel arbitration." "158 I do not see how it could be otherwise, assuming the courts are to have any responsibility for the merits. There is a difference between a pediatrician's responsibility for a newly betrothed woman and for a newly born child. As I have elaborated elsewhere, ${ }^{168} \mathrm{I}$ believe that, at least as between the parties themselves, the arbitration award is the parties' own agreed-upon "reading" of their contract, and that, within certain well-recognized limitations, the courts are in the business of enforcing contracts. But Meltzer placed his rationale on a loftier level. Invoking the "responsible exercise of judicial power," he argued that courts should not be required "to rubber-stamp the awards of private decision-makers when the courts are convinced that there is no rational basis in the agreements for the awards they are asked to enforce."160

However divergent our rationales, our positions converge. Both of us would agree that a court should decline to enforce an award that has no rational basis. I would simply say that a court should do so in order to preserve the intent of the parties (who

138 Id. at 202-03.

${ }^{157}$ Meltzer, Ruminations About Ideology, Law, and Labor Arbitration, 34 U. CHI. L. REv. 545 (1967).

${ }^{188}$ Id. at 553.

${ }_{159}$ See St. Antoine, Judicial Review of Labor Arbitration Awards: A Second Look at Enterprise Wheel and Its Progeny, 75 Mrch. L. REv. 1137, 1140-41 (1977).

${ }_{160}$ Meltzer, supra note 157, at 553-54. 
presumably selected their arbitrator on the assumption that he or she was not insane, irrational, or corrupt), rather than to preserve its own integrity. Yet as a practical matter, I recognize much truth in Meltzer's observation that "the unique attempt to shrivel judicial responsibility in enforcing arbitration awards is likely to fail because it runs against the grain of judicial tradition." "We also see eye-to-eye on the competing values at stake: even "drastically limited judicial review" creates "serious risks" for the vitality of the arbitration process, which depends upon a "tradition of judicial self-limitation." ${ }^{162}$

In addressing the much-bruited question of the arbitrator's responsibility when "there is an irrepressible conflict" between the contract and the law, Meltzer was blunt: "the arbitrator, in my opinion, should respect the agreement and ignore the law."16s I think both principle and practical considerations support his view. The leading Supreme Court case, United Steelworkers of America v. Enterprise Wheel \& Car Corp., ${ }^{164}$ itself declares that an arbitrator who makes an award "based solely on [his] view of the requirements of enacted legislation" exceeds his authority. ${ }^{165}$ Moreover, arbitrators, many of whom are not even lawyers, may have no special expertise in complex and changing statutory areas. A conscientious arbitrator can retain his integrity and avoid misleading the parties by noting that he is not passing on the legality of a questionable contractual provision.

As a practical matter, of course, the intellectual high jinks of the great contract-versus-law debate are of limited concern. Arbitrators have always interpreted the law and always will. An arbitrator may often have occasion to turn to a statute for guidance in interpreting a particular contractual provision, especially if the contract was written to parallel the legislation. And, as Meltzer correctly pointed out, genuine ambiguities can always be construed so as to make the contract compatible with the law. ${ }^{166}$ I strongly suspect that the strategem of resolving contractual ambiguities so as to avoid conflict with the statute enables most arbitrators to avoid ever facing the storied choice. There are but few conflicts that cannot, in Meltzer's words, be repressed.

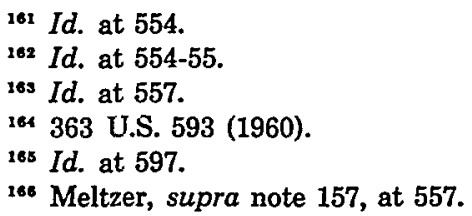




\section{The Law of Racial Discrimination}

The problem of racial discrimination in employment raises many of the kinds of issues most likely to attract Meltzer's critical eye. Attempts to read broad social justice into labor statutes and collective bargaining agreements present now-familiar concerns: preserving the integrity of the statutory scheme and of the parties' bargain, and establishing the proper boundaries of the roles of arbitrators, the Board, and the courts. And the perplexing question of the legality of private-sector affirmative action plans occasioned Meltzer's most recent return to what is perhaps his most central theme-- that the Court must do its job well.

A. On Reading a Ban on Racial Discrimination into the National Labor Relations Act

The Taft-Hartley Act, which was enacted over a presidential veto by a Congress in a conservative $\operatorname{mood},{ }^{167}$ for the first time made it an unfair labor practice for a union (as it had previously been for an employer) to coerce or discriminate against employees because of their participation or nonparticipation in organizational activities. ${ }^{168}$ Hubert Humphrey tried to push his party further in the direction of labor law reform a year later by waging a bitter battle to include a plank in the Democratic party platform supporting the creation of a congressional Fair Employment Practices Committee. The same Congress that enacted Taft-Hartley subsequently rejected Humphrey's proposal without hesitation, against the wishes of victorious presidential candidate Harry Truman. ${ }^{169}$

The Taft-Hartley Congress hardly seemed to have intended to initiate a liberal social agenda in the field of labor relations. Yet some seventeen years later, in the very year in which Congress finally and explicitly outlawed racial discrimination in employment by passing Title VII of the 1964 Civil Rights Act, ${ }^{170}$ the Board managed to hold, in the face of this history, that prior labor statutes had already accomplished much of the task. A union that refused to process a black employee's grievance, the Board declared, was guilty of an unfair labor practice under the Taft-Hartley Act and was not entitled to remain certified as the employees' exclusive

${ }^{167}$ See Philip Taft, Organized Labor in American History 579-83 (1964); Foster Rhea Dulles, Labor in America: A History 372-73 (1949).

${ }^{168} 29$ U.S.C. \& 158(b)(1)-(2) (1982).

169 See Bernard Baityn et al., The Great Republic 115 (1977).

170 Title VII, $\S$ 701-704, Pub. L. No. 88-352, 78 Stat. 253-57 (codified as amended at 42 U.S.C. $\S \S 2000 \mathrm{e} 1-\mathrm{e} 3(1982))$. 
bargaining agent. ${ }^{171} \mathrm{~A}$ decade later two courts of appeals went even further, holding that under the Wagner Act an employer could assert a union's discriminatory membership practices as a defense to a bargaining order, ${ }^{172}$ and that an employer could not discharge black employees who refused to abide by a contractual grievance procedure but instead engaged in concerted picketing to get the employer to deal directly with them. ${ }^{173}$

Meltzer could easily have chided the Board and the courts for infidelity to congressional intent, but he preferred a more functional critique of incorporating a ban on racial discrimination into the preexisting law of labor-management relations. Introducing discrimination issues into representation cases, he asserted, would inevitably lengthen proceedings, thus increasing the likelihood of erosion of employee support for the union due to delay. ${ }^{174}$ Allowing minority groups within bargaining units to deal directly with their employer would require the Board to apply an "unworkably vague" standard in determining which blocs of employees were no longer subject to the principle of exclusive representation. Separate dealings had the potential to destroy orderly collective bargaining, to undercut policies against protracted recognitional picketing and in favor of arbitration, and to disrupt industrial peace. ${ }^{175}$ The Supreme Court and the Board were eventually to see it Meltzer's way. ${ }^{176}$

173 Independent Metal Workers, Local No. 1 (Hughes Tool Co.), 147 N.L.R.B. 1573, 1577-78 (1964). The majority of the Board in Hughes Tool reiterated the position it took in an earlier case, Miranda Fuel Co., 140 N.L.R.B. 181 (1962), enforcement denied, 326 F.2d 172 (2d Cir. 1963), in which it first held a union's breach of its duty of fair representation to be an unfair labor practice. That position was later upheld by the Fifth Circuit. See Local Union No. 12, United Rubber Workers v. NLRB, 368 F.2d 12 (5th Cir. 1966); see also infra note 176.

172 NLRB v. Mansion House Center Management Corp., 473 F.2d 471, 473-74 (8th Cir. 1973) (relying in part on the due process clause). But cf. Bell \& Howell Co., 230 N.L.R.B. 420,421 (1977) (denying the applicability of the due process clause), enforced, 598 F.2d 136 (D.C. Cir.), cert. denied, 442 U.S. 942 (1979). The Board has not been consistent as to when it will consider the issue of race discrimination. It initially held that claims of invidious discrimination would be heard in representation proceedings, see Bekins Moving \& Storage Co., 211 N.L.R.B. 138 (1974) (but holding also that consideration after union wins election is adequate), but later reversed itself by holding that discrimination claims would only be considered in unfair labor practice proceedings, see Handy Andy, Inc., 228 N.L.R.B. 447 (1977).

${ }^{173}$ Western Addition Community Org. v. NLRB, 485 F.2d 917 (D.C. Cir. 1973), rev'd sub nom. Emporium Capwell Co. v. Western Addition Community Org., 420 U.S. 50 (1975).

174 Meltzer, The National Labor Relations Act and Racial Discrimination: The More Remedies, the Better? 42 U. CHI. L. REv. 1, 15 (1974).

173 Id. at $32,35$.

${ }^{170}$ See supra notes 172,173 . Meltzer did not directly address one important issue, the notion that a union which discriminates on the basis of race violates its duty to represent all 


\section{B. Arbitration and Title VII}

On the appropriate role of the arbitrator in dealing with Title VII discrimination issues, Meltzer was as direct as he was in dealing with arbitration in general: the arbitrator should follow the contract regardless of any apparent conflict with the statute. ${ }^{177} \mathrm{Ar}$ bitrators lack "institutional" competence "with respect to awards enforcing the law and abrogating the contract."178 This position, based on the view that arbitral and judicial remedies should remain distinct, had two corollaries: an arbitral ruling on discrimination should not foreclose an independent judicial determination, and an employee should not be required to exhaust contractual procedures before invoking statutory remedies against discrimination. ${ }^{178}$

In the leading case of Alexander v. Gardner-Denver Co., ${ }^{180}$ the Supreme Court essentially adopted Meltzer's position against arbitral foreclosure of Title VII claims. Although the Court noted that "the specialized competence of arbitrators pertains primarily to the law of the shop, not the law of the land"181_which had been Meltzer's primary rationale-the Court laid greater emphasis on other factors. The Court noted that discrimination involves individual rights not created by statutory processes of union representation and collective bargaining, rights which are thus not waivable by unions that enter arbitration agreements. ${ }^{182}$ The general intent of Congress to grant overlapping remedies against discrimination also argued against foreclosure of Title VII claims. ${ }^{183}$ The Court clouded the issue, however, by stating in dictum that in appropriate circumstances a prior arbitral award could be admitted and accorded "great weight" in Title VII proceedings, but that courts must nonetheless safeguard the "full availability" of the judicial forum. ${ }^{184}$

employees, and thereby commits an unfair labor practice. See supra note 171 and accompanying text. He did note, however, that the Board's power to revoke certification was rarely used "and was probably viewed as a paper tiger." Meltzer, supra note 174, at 4 . The Supreme Court has apparently accepted the notion that union racial discrimination is an unfair labor practice. See Vaca v. Sipes, 386 U.S. 171, 182-83 (1967) (discussing Miranda Fuel and concluding that it does not require preemption under Garmon).

${ }^{177}$ See supra note 163 and accompanying text.

178 Meltzer, supra note 3, at 33-34.

${ }^{179} \mathrm{Id}$. at $42-45,47$.

180415 U.S. 36 (1974).

${ }^{181}$ Id. at 57; see also id. at 52 n.16 (citing Meltzer).

${ }^{182}$ Id. at 51-52.

${ }^{183}$ Id. at $47-49$.

184 Id. at 60 n.21. 
As Meltzer later pointed out, the Court in Gardner-Denver "did not pause" to address the question of arbitral enforcement of contract provisions "similar to or duplicative of" federal antidiscrimination laws. ${ }^{185}$ As a reaction to Gardner-Denver, both "expansionist" and "limitist" proposals for new collective bargaining provisions were sounded in various quarters. The former would have given arbitrators explicit authority to apply all applicable antidiscrimination law and to invalidate and rewrite the parties' contracts as necessary. Limitist proposals, on the other hand, would have excluded grievances that are cognizable under Title VII from arbitration. Not surprisingly, Meltzer was hostile to both extremes. Private enforcement of public policy was not an unmitigated good. Employer and union consent to expansionist clauses, he worried, might be "formal rather than real," and the very qualities that make arbitration so valuable in "a system of private ordering"-its informality, privacy, ad hoc recruitment of personnel, and so on-"compromise it as an instrument of important public purposes."186

I agree with Meltzer's rejection of these so-called expansionist clauses on practical grounds: they would hardly be likely to lead the federal judiciary to grant true deference to the arbitration of Title VII claims. ${ }^{187}$ But on a theoretical level, I see no reason to prevent an agreeable set of parties from authorizing a qualified arbitrator to subordinate the contract to his interpretation of enacted law in pursuit of greater finality. As to limitist proposals, I agree fully with Meltzer that they are quite unrealistic. Discrimination claims, often interwined with other issues, are legion in today's grievance machinery. Their total exclusion from arbitration would drastically curtail the scope of the arbitration process. ${ }^{188}$ Ever mindful that arbitration is more a substitute for economic warfare than for judicial process, Meltzer was wisely protective of its role. ${ }^{189}$

185 Meltzer, Labor Arbitration and Discrimination: The Parties' Process and the Public's Purposes, 43 U. Cri. L. Rev. 724, 725 (1976).

${ }^{286}$ Id. at 729-30.

${ }^{187}$ Meltzer suggested this result as well. See id. at 732-33.

${ }^{188}$ Cf. Edwards, Advantages of Arbitration over Litigation: Reflections of a Judge, 35 NAT'l ACAD. ARb. Proc. 16, 21-22, 27-28 (1983) (discussing superiority of arbitration over adjudication for resolving typical arbitrable issues, partly because exclusion of public law issues from scope of arbitration simplified the process).

${ }^{180}$ See Meltzer, supra note 3, at 34. 


\section{Affirmative Action}

Affirmative action is an issue guaranteed to bring out the best and the worst in Meltzer. He knew, as anyone who scans the legislative history with an unbiased eye would know, ${ }^{190}$ that the Congress which enacted Title VII of the Civil Rights Act in 1964 had color-blindness as its guiding principle. And the statutory language could hardly have more clearly incorporated that standard than by forbidding employers (or unions) "to discriminate against any individual . . . because of such individual's race, color, religion, sex, or national origin."101

In Steelworkers v. Weber, ${ }^{182}$ the Supreme Court upheld a "private, voluntary" affirmative action plan that was the product of collective bargaining. The plan reserved for black employees fifty percent of the openings in an in-house craft-training program. The racial quota was to terminate when the percentage of black craftworkers in the previously segregated plant became commensurate with the percentage of blacks in the local labor force. Until that time, however, black employees who applied for the training program were preferred over white applicants with greater seniority.

Justice Brennan, writing for the majority, first emphasized that the case presented solely a "narrow statutory issue": since the union-employer plan involved no state action, no constitutional question was raised under the equal protection clause of the fourteenth amendment. ${ }^{193}$ Then, conceding that a literal interpretation of Title.VII as prohibiting all race-conscious programs was "not without force," 194 he turned to the spirit of the legislation and concluded that "it would be ironic indeed if a law triggered by a $\mathrm{Na}$ tion's concern over centuries of racial injustice . . . constituted the first legislative prohibition of all voluntary, private, race-conscious efforts to abolish traditional patterns of racial segregation and hi-

190 For an extraordinarily convincing survey of the congressional debates, see Steelworkers v. Weber, 443 U.S. 193, 230-52 (1979) (Rehnquist, J., dissenting).

19142 U.S.C. § 2000e-2(a)(1) (1982) (employers); id. § 2000e-2(c)(1) (labor organizations); id. $\S 2000 \mathrm{e}-2(\mathrm{~d})$ (employers or labor organizations in control of training programs).

182443 U.S. 193 (1979) (5-2 decision).

${ }^{193}$ Id. at 200 . Justice Brennan did not, however, take note of the fact that the plan may have been adopted at least in part in response to pressure from the U.S. Office of Federal Contract Compliance. See 443 U.S. at 246 (Rehnquist, J., dissenting); Meltzer, The Weber Case: The Judicial Abrogation of the Antidiscrimination Standard in Employment, 47 U. Chr. L. Rev. 423, 438 n.73, 443-44, 446 (1980).

104443 U.S. at 201. 
erarchy." "195 Justice Brennan bolstered his position by pointing to section 703(j) of the Act, which provides that nothing in Title VII shall "require" any employer to grant preferential treatment. ${ }^{196}$ Had Congress wished, it could have just as easily disclaimed the intent to "permit" as well as the intent to "require" preferential treatment as a remedy for racial imbalance. Instead, he argued, Congress chose not to limit managerial freedom to employ certain justifiable racial preferences. ${ }^{197}$

Meltzer was devastating in dealing with the notion that the "statutory purpose identified by the majority-to help blacks get jobs"198_required the result reached by the majority. To Meltzer, "under the statute that end . . . was to be advanced by a particular means": by equal opportunity rather than by preferences in employment. ${ }^{199}$ Meltzer also embraced Justice Rehnquist's effective refutation of the argument from section $703(j)$. The provision was inserted in specific response to the objection that the Act would authorize courts and agencies to force preferential treatment of minorities on unwilling employers; Congress did not need to address voluntary preferences because they were banned by the general prohibitory language of Title VII. ${ }^{200}$

Meltzer was surely correct that Justice Brennan's opinion in Weber lacked the "power to convince." 201 But Meltzer failed to consider the severe tactical handicap that constrained Justice Brennan's effort to marshal a majority. Justices Powell and Stevens did not participate in Weber. The Bakke case, ${ }^{202}$ which involved medical-school admissions quotas, had established an alignment of Justices which, if carried over to Weber unchanged, would have resulted in a four-to-three majority in favor of affirmative action: too narrow and indecisive a result for the first Supreme Court test of this important issue in the employment field. ${ }^{203}$ Justice

195 Id. at 204.

19842 U.S.C. $\$ 2000 \mathrm{e}-2(\mathrm{j})(1982)$.

197443 U.S. at 204-07.

${ }^{198}$ Meltzer, supra note 193, at 446.

199 Id. at $446-47$ (emphasis added).

200433 U.S. at 244-46 (Rehnquist, J., dissenting); Meltzer, supra note 193, at 445-46. It is possible, of course, that members of Congress simply failed to imagine the possibility of voluntary implementation of affirmative action plans.

${ }^{201}$ Meltzer, supra note 193, at 465.

${ }^{202}$ Regents of the Univ. of Cal. v. Bakke, 438 U.S. 265 (1978). Bakke involved Title VI of the Civil Rights Act of 1964,42 U.S.C. $\S 2000$-d (1982), which prohibits discrimination by recipients of federal funding.

${ }^{203}$ The core four members of the Weber majority, Justices Brennan, White, Marshall, and Blackmun, had joined in an opinion in Bakke which broadly endorsed the remedial use of racial classifications under both Title VI and the equal protection clause. See Bakke, 438 
Stewart's switch from his anti-quota position in Bakke was critical to Justice Brennan's commanding five-to-two majority in Weber. ${ }^{204}$

Justice Stewart seemed to be more averse to public than to private racial preferences. ${ }^{205}$ It was therefore probably vital, in order to gain his vote, that Justice Brennan refrain from any grounds for the Weber decision that would broaden the preexisting scope of the Court's approval of governmental affirmative action. ${ }^{206}$ Justice Brennan was thus deprived of an argument that would have bolstered his position. He could have argued that Congress was aware when it amended Title VII in $1972^{207}$ that a court of appeals had sustained a presidential affirmative action program for government contractors against constitutional and statutory challenges. ${ }^{208}$ Senator Sam Ervin had offered two amendments to Title VII, in part in response to that executive program. ${ }^{208}$ The defeat of his amendments by two-to-one margins ${ }^{210}$ would suggest that Congress did not understand the general prohibition of discrimination in Title VII as a ban on affirmative action plans. This argument, however, would implicate governmental affirmative action plans, since the case and the ensuing debate concerned action by the executive branch. To make the argument might have placed Justice Stewart's vote at risk.

U.S. at 324 (Brennan, J., concurring in part and dissenting in part).

204 In Bakke, Justice Stewart had joined in an opinion that rejected the quota on purely statutory grounds. 438 U.S. at 408 (Stevens, J., concurring in part and dissenting in part). While Bakke involved Title VI and Weber involved Title VII, the opinion Justice Stewart joined in Bakke gave no indication that it adopted a definition of "discrimination" which was unique to Title VI. See id. at 413 ("Title VI is an integral part of the far-reaching Civil Rights Act of 1964").

${ }^{205}$ It would be a mistake to say that Justice Stewart was completely comfortable with the private use of racial classifications. See Fullilove v. Klutznick, 448 U.S. 448, 532 (1980) (Stewart, J., dissenting) (arguing against governmental use of racial classifications in part because it will foster private discrimination). However, his opinion in Fullilove was centrally concerned with constitutional requirements and the proper role of courts and legislatures in the light of those requirements, see id. at 523-28, concerns that are not implicated by private affirmative action plans.

${ }^{206}$ Justice Brennan's opinion in Bakke rested in part on constitutional grounds, see supra note 203; the opinion joined by Justice Stevens expressly rejected Justice Brennan's effort to declare the "constitutional effects of this Court's judgment" in Bakke, see 438 U.S. at $408 \mathrm{n} .1$ (Stevens, J., concurring in part and dissenting in part). No opinion commanded a majority, thus leaving the major issues unresolved.

207 Equal Opportunity Act of 1972, Pub. L. No. 92-261, 86 Stat. 103 (codified at 42 U.S.C. $\S \S 2000 \mathrm{e} 1-2000 \mathrm{e} 17$ (1982)).

${ }^{208}$ Contractors Ass'n v. Secretary of Labor, 442 F.2d 159 (3d Cir.), cert. denied, 404 U.S. 854 (1971).

${ }^{209} 118$ CONG. Rec. 1663, 4918 (1972) (discussing Philadelphia plan at issue in Contractors).

${ }^{210}$ Id. at $1676,4918$. 
The most profound failure of the Weber opinion, its unwillingness to come to grips with the meaning of the term "discriminate," can also be explained by the desire to avoid a holding with broad constitutional significance. Meltzer alluded in a footnote to Justice Brennan's failure to address the critical distinction between "benign" and "malign" discrimination, but did not pursue the question in depth. ${ }^{211}$ For me the issue is central. I believe that there is a fundamental moral and legal difference between action taken by a majority to foster participation by a previously excluded minority and action taken to perpetuate that minority's exclusion. ${ }^{212}$ This difference must be taken into account despite the immense practical difficulties always inherent in the need to draw lines.

Meltzer clearly recognized the core issue presented by the Weber case. He was close to the mark when he declared: "Weber is, in fact, an important step in the transformation of the classic and widely supported liberal ideal of equal opportunity for individuals into a new program of equal outcomes for groups."213 But ultimately I think he missed the mark. "Equal outcomes" is the giveaway. I know of no serious advocate of affirmative action who would go so far as to seek "equal outcomes for groups." This overstatement is one of the rare occasions on which I have detected Meltzer indulging in the sort of loose rhetoric he so properly indicts in others. Advocates of affirmative action are simply willing to acknowledge the possibility that white America has perpetrated a wrong against blacks as a group that is so deep and so pervasive that attempts to identify individual victims are at best futile, at

211 Meltzer, supra note 193 , at 440 n.84.

212 See, e.g., Ronald Dworkin, Taking Rights Seriously 223-39 (1977). For a debate on the issue, see Ely, The Constitutionality of Reverse Racial Discrimination, $41 \mathrm{U}$. CHI. L. REv. 723, 728-36 (1974); Posner, The DeFunis Case and the Constitutionality of Preferential Treatment of Racial Minorities, 1974 Sur. CT. Rev. 1; Sandalow, Racial Preferences in Higher Education: Political Responsibility and the Judicial Role, 42 U. CHI. L. REv. 653 (1975) (discussing the opposing views of Ely and Posner). For a reflection of the debate in the popular literature, see Cohen, Why Racial Preference Is Illegal and Immoral, CommenTARY, June 1979 , at 40,44 .

The cited authorities are primarily concerned with constitutional standards of "equal protection," about which it is difficult to make seemingly conclusory arguments from "plain meaning." But even the meaning of the arguably less elastic term "discriminate" is subject to interpretation. Today the term often connotes invidious distinctions, not mere line-drawing. As one of our most distinguished federal judges has remarked, "to discriminate .. . more often means, both in common and particularly in legal parlance, to distinguish or differentiate without sufficient reason." NLRB v. Miranda Fuel Co., 326 F.2d 172, 181 (2d Cir. 1963) (Friendly, J., dissenting) (emphasis added). If Judge Friendly is correct, "discrimination" analysis inevitably draws us to an evaluation of whether (and how well) a distinction serves the purposes of an otherwise valid statutory scheme.

${ }^{213}$ Meltzer, supra note 193, at 456. 
worst a mockery of justice. While Meltzer is receptive to an attack on unequal conditions that would be based on "need or disadvantage-a criterion that [is] a better measure of inequality of condition and less troublesome-morally and politically-than race,"214 I can only testify sadly to my doubt that there exists a mature American black who is not disadvantaged. It is better, in my view, to adopt a legal standard which openly acknowledges the moral and political quandary that has resulted from our history of group discrimination.

It goes almost without saying that Meltzer asked hard, probing, practical questions about what is needed to move blacks into the mainstream of the economy. He was concerned, for instance, that official pressure for affirmative action might contribute to the flight of business from black population centers, "intensify racial politics and further polarize our work forces and our communities."215 In the past I worried about similar questions, and I do not now mean blithely to dismiss them. But I have become increasingly aware that few blacks outside academia share such concerns. For them, affirmative action is worth the risks-and I am prepared to abide by their judgment of their best interests. I also rely on white self-interest to bring this unique societal experiment to a halt as soon as it has achieved its goal of a truly integrated work force-if not sooner.

\section{A Personal Conclusion}

It has been a privilege to retrace the path of one of the great pioneering figures in labor law scholarship. As has probably become clear, I do not share all of Professor Meltzer's values and attitudes. It has gradually dawned on me during this intellectual journey, however, that I know of no person in the entire field of labor relations who is so adept at asking all the right questions, recognizing all the competing interests, and exposing all the ancient shibboleths. I observed earlier that he suffers from the defects of his virtues: I am not prepared to nominate Professor Meltzer as the foremost philosopher of labor law. But my traversal of his work has led me to conclude that he deserves the title which any good worker would say is only a little less exalted: he is our finest craftsman. 